\title{
Criteria for recognition of localization and timing of multiple events of hydrothermal alteration in sandstones illustrated by petrographic, fluid inclusion, and isotopic analysis of the Tera Group, Northern Spain
}

\author{
Laura González-Acebrón · R. H. Goldstein · \\ Ramón Mas · José Arribas
}

\begin{abstract}
Stratigraphic relations, detailed petrography, microthermometry of fluid inclusions, and fine-scale is topic analysis of diagenetic phases indicate a complex thermal history in Tithonian fluvial sandstones and lacustrine limestones of the Tera Group (North Spain). Tw• different thermal events have been recognized and characterized, which are likely assøciated with hydrothermal events that affected the Cameros Basin during the midCretaceous and the Eøcene. Multiple stages of quartz cementation were identified using scanning electron microscope cathodoluminescence on sandstones and fracture fills. Primary fluid inclusions reveal homøgenization temperatures (Th) from 195 to $350^{\circ} \mathrm{C}$ in the quartz cements -f extensiønal fracture fillings. The high variability $\bullet$ Th data in each particular fluid inclusion assemblage is related to natural reequilibration of the fluid inclusions, probably due to Cretaceøus hydrøthermal metamorphism. Søme secondary fluid inclusion assemblages show very consistent data $\left(\mathrm{Th}=281-305^{\circ} \mathrm{C}\right)$ and are considered not to have
\end{abstract}

L. González-Acebrón ( $\square) \cdot$ R. Mas

Dpto. Estratigrafía, Facultad de Ciencias Geológicas (UCM), Instituto de Geología Económica (CSIC),

C/ Jose Antonio Novais 2, 28040 Madrid, Spain

e-mail: lgcebron@geo.ucm.es

R. H. Goldstein

Department of Geology, University of Kansas,

1475 Jayhawk Blvd., Lawrence, KS 66045, USA

J. Arribas

Dpto. Perología y Geoquímica, Facultad de Ciencias Geológicas (UCM), Instituto de Geología Económica (CSIC),

C/ Jose Antonio Novais 2, 28040 Madrid, Spain reequilibrated. They are likely related to an Eøcene hydrothermal event or to a retrograde stage of the Cretaceøus hydrothermalism. This apprøach shows how multiple thermal events can be discriminated. A very steep thermal gradient of $97-214^{\circ} \mathrm{C} / \mathrm{km}$ can be deduced from $\delta^{18}$ values of ferroan calcites $\left(\delta^{18}-14.2 /-11.8 \%\right.$ V-PDB) that postdate quartz cements in fracture fillings. Furthermore, illite crystallinity data (anchizone-epizøne boundary) are -ut of equilibrium with high fluid inclusion Th. These -bservations are consistent with heat-flux related to shortlived events of hydrothermal alteration focused by permeability contrasts, rather than to regional heat-flux associated with dynamø-thermal metamorphism. These results illustrate how thermal data from fracture systems can yield thermal histories markedly different from hostrock values, a finding indicative of hydrothermal fluid flow.

Keywords Quartz cements - Fluid inclusions Thermal evolution - SEM-CL - Camer basin

\section{Introduction}

Withøut significant fluid fløw, the spatial and temporal distribution of diagenetic and low-grade metamorphic alteration in siliciclastic sequences is thøught to be predictable on the basis of burial depth history, thermal regime, and composition (eg. Bjørlykke 1998; Morad et al. 2000). Relatively few studies, however, have examined the influence of significant flow of hydrothermal fluids on sandstone diagenesis and low-grade metamorphism (e.g., Røssi et a1. 2002; Ochøa et a1. 2007). In these hydrothermal systems, sandstone alteration departs from the predicted diagenetic model because of transport of heat, sølvent, and sølute. Research on hydrothermal alteration of carbonate 
strata, in contrast, has received significant attention in recent years, resulting in the focus of an entire issue of a scientific journal and many $\bullet$ ther publications (e.g. Davies and Smith 2006). Discriminating hydrothermal from •ther regimes of diagenetic alteration is a key component in much of the recent literature on this subject (e.g. Machel and Lonnee 2002; Esteban and Taberner 2003; Hiemstra and Gøldstein 2005; Davies and Smith 2006; Gøldstein in press).

This study contributes to bringing siliclastic diagenesis and low-grade metamorphic studies up-to-speed by providing an example of a hydrothermally affected siliciclastic sequence. In doing sø, it develops apprøaches for identifying where hydrothermal alteration in siliciclastics has -ccurred, and elucidates novel techniques to document hydrothermal alteration, invølving cathodøluminescence petrography, fluid inclusions, and other geothermometers.

Detecting, dating, and determining the origin of multiple thermal events in sandstones subjected to diagenesis and low-grade metamorphism are challenging, due to the scarcity of applicable gethermømeters, gebarømeters, dating techniques, and prøblems with resetting during alteration (De Caritat et a1. 1993; Essene and Peacor 1995, 1997). This commonly results in the •versimplified inter-

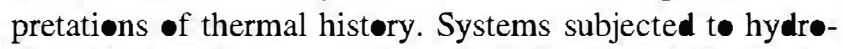
thermal alteration are particularly difficult tø work with, as they may have experienced multiple short-lived pulses of fluid flow, each driven by different geølogic mechanisms (e.g. Coveney et a1. 2000). In this study, the integration -f scanning electron microscope cathodoluminescence (SEM-CL) with fluid inclusion microthermometry (e.g. G॰ldstein and Røssi 2002) and other published work on timing has proven useful in reconstructing timing and -rigin of multiple hydrøthermal events. For this, we study host rock and fracture fillings of Upper Jurassic sandstone -f the Camerøs Basin in Spain. Althøugh it is understood that many $\bullet$ the fluid inclusions in løw-grade metamorphic systems suffer from reequilibration, making straightforward interpretation of data difficult (e.g. Turgarinev and Vernadsky 1970; Lacazette 1990; Gøldstein and Reynolds 1994), in this study, most of the fluid inclusion assemblages show signs of having been only partially reequilibrated. Thus, they still prove useful in interpreting thermal history thanks to a detailed petrographic analysis including SEM-CL on quartz cements. This study provides a model for how multiple hydrothermal events can be discriminated in sandstones.

The Cameros Basin represents one of the Mesøuic Iberian Basins and the only one that shøws metamørphism in the Iberian Range (e.g. Mas et a1. 2002, 2003). More specifically, the metamorphism affected a large proportion -f the depøsits of the Eastern Camerøs Basin (e.g. Casquet et a1. 1992; Mantilla-Figuerøa et a1. 2002). The basin infill is composed of a thick sequence of continental sedimentary rocks, generate under an extensional regime characterized by high rates $\bullet$ subsidence, frøm the Tithønian to the Early Albian. This research is focussed on Tithønian strata of the Tera Group, a thick succession deposited in the eastern sector of the Cameros Basin during its first rifting stage (Figs. 1 and 2).

Early on dynam-thermal metamorphism was considere to have $\bullet c c u r r e d$ during the infilling $\bullet$ the Camer Basin (Guiraud and Seguret 1985; Gølberg et a1. 1988). This model of burial metamorphism is still maintained by -ther authørs (Casas-Sáinz, Simón-Gómez 1992; Mata et al. 2001; Del Rí et al. 2009). These studies are based on an interpretation of the basin structure as a synclinal basin. In contrast, the thermal evolution of the eastern sector of the basin has been studied using radiometric dating (K-Ar), mineral assemblages, crystal chemical parameters of phylløsilicates, chlorite thermometry, and is topic thermømetry of sulfide deposits. These studies recognize a thermal event (Casquet et al. 1992; AlønsAzcárate et a1. 1995; Barrenechea et a1. 1995, 2000; Mantilla-Figuerøa et a1. 1998; Aløns-Azcárate et al. 1999; Mas et a1. 2003), which was characterized as lowto very low-grade hydrothermal metamorphism (Late Albian-Coniacian).

Our study is focused on fluid inclusion microtherm๑meric data from quartz in extensional fracture fillings in the Tera Group, which are the likely focus zones for hydrothermal fluids (San Felices section, SAN), and quartz -vergrowth cements in areas away from the these zones (El Espin॰ section, ESP). The filled fractures are observable in the field (SAN) and have been interpreted to form during the extensional stage of basin formation (Guiraud and Seguret 1985; Mantilla-Figuerøa 1999; Mata et a1. 2001). The principal aims of this paper are as follows: (1) to compare the thermal histories of fracture fillings and host røcks in a basin affected by a løw-grade metamørphism taking in consideration both diagenetic and hydrothermal processes, (2) to characterize the water-røck interaction in

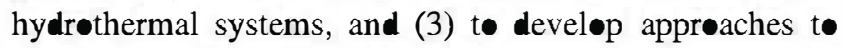
discriminate between different low-grade metamorphic processes in sedimentary basins.

\section{Geological and stratigraphic setting}

\section{Basin formation}

The Camerøs Basin in the nørthern Iberian Range (Fig. 1) førms part $\bullet$ the Mesøzic Iberian Rift System (Mas et al. 1993; Guimerà et a1. 1995; Salas et a1. 2001; Mas et a1. 2002). Intraplate rifting was a consequence of a generalized extensional regime, which separated Iberia from Europe. 


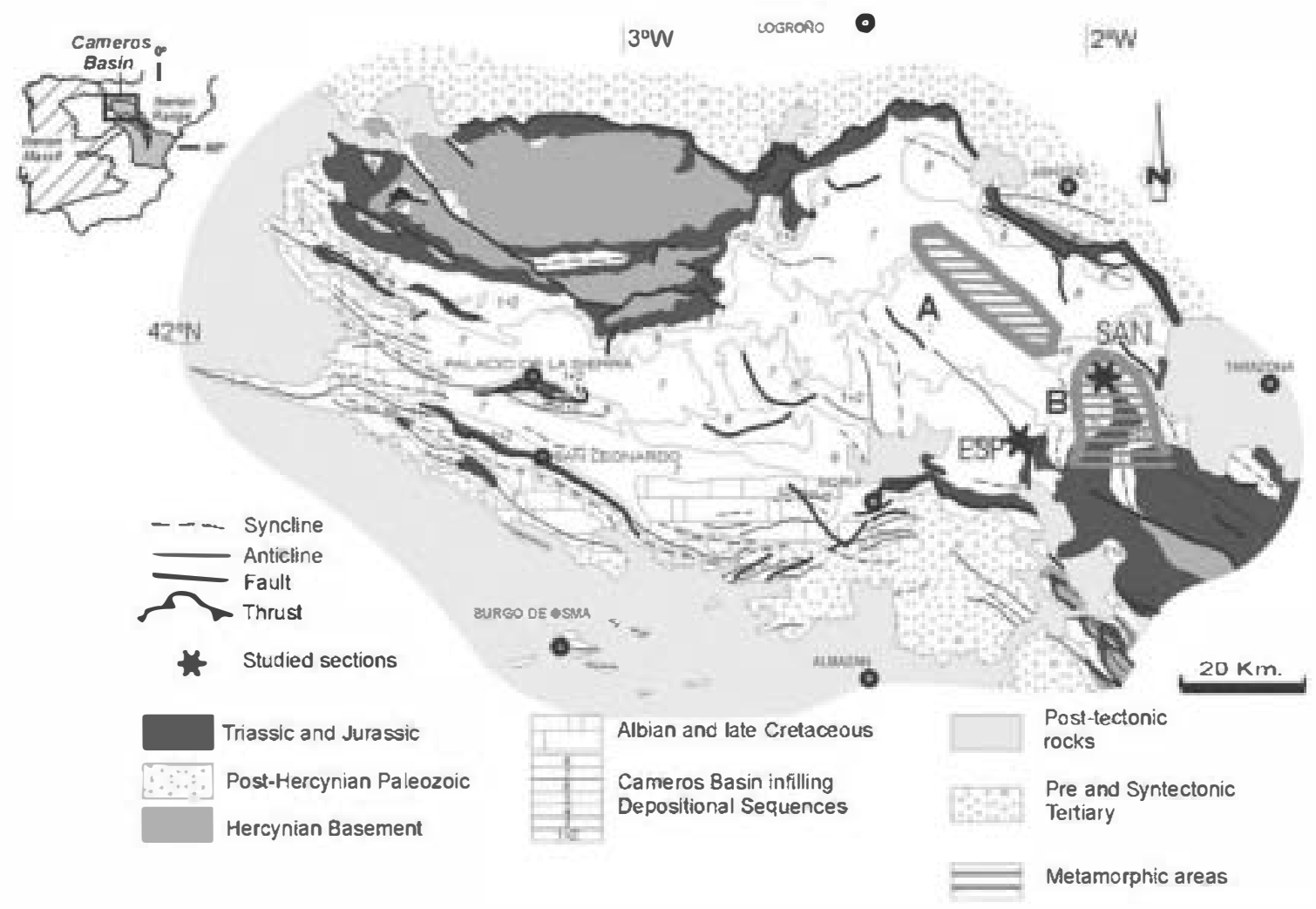

Fig. 1 Geologic map of the Cameros Basin indicating the SAN section (E1 Pégado anticline) and the ESP section. The areas affected by low-grade and very low-grade hydrothermal metamorphism are

The subsidence and sedimentation rates in the Cameros Basin were very high, with vertical thicknesses up to $6 \mathrm{~km}$ and up to $9 \mathrm{~km}$ of statigraphic record in the direction of the northward migration of depositional sequences recorded from the Tithonian the early Albian. The basin has been interpreted as a hanging wall synclinal basin (extensional-ramp basin) formed over a roughly south-dipping ramp between twe nearly horizontal sections (flats) in a deep extensional fault inside the Variscan Basement. The northern flat is $7 \mathrm{~km}$ depth and the southern flat $11 \mathrm{~km}$ depth (Guimerà et a1. 1995). The direction of displacement for the hanging wall was S-SW, parallel to the direction of the basin extension (Mas et a1. 1993, 2002, 2003; Guimerà et a1. 1995, 2004). Alternatively, Guiraud and Seguret (1985), Casas-Sainz and Gil-Imaz (1998), Mata et al. (2001), Villalaín et al. (2003) and Casas-Saínz et al. (2009) interpreted the Cameros Basin as a synclinal basin, with vertical superposition of Løwer Cretaceøs sedimentary units rather than laterally juxtaposed bodies overlapping the prerift sequence. These authors consider a thrust fault to the north as a result of tectonic inversion of a normal fault generated at the beginning of the Cretaceous, which reached the Keuper facies in depth. This hypothesis has a mechanical flaw that makes it unlikely (Mas et a1. 1993, indicated: a Yanguas-San Pedro Manrique area. b El Pégado anticline. Modified from Mas et al. (2002)

2002, 2003; Guimerà et a1. 1995). The hypothesis of Guiraud and Seguret (1985) would require a slab of Jurassic rocks, only 500-800 m thick but more than $30 \mathrm{~km}$ wide and $100 \mathrm{~km}$ long, to be pulled from the South without suffering any break in continuity and without forming a fault over the ramp near the northern basin margin. This would have had to occur under subaerial conditions because of the continental nature of the rocks that filled the basin. Their model would require, an even more unlikely, later reverse displacement of tens of kms to the North, still somehow maintaining the continuity of the marine Jurassic substrate after the Cenøeic contraction.

\section{Basin infill}

The basin record essentially consists of continental sedimentary rocks corresponding to alluvial and lacustrine systems, with rare marine incursions (Mas et al. 1993; Gómez-Fernández and Meléndez 1994). The sedimentary infill of the Cameros Basin has been divided into eight depesitional sequences (Mas et a1. 2002, 2003) (Fig. 2). The Tera Group represents the first stage of rifting sedimentation and is formed by two depositional sequences (DS 1 and DS 2, Fig. 2), which are Tithonian in age (Mas et a1. 1993, 2004; 


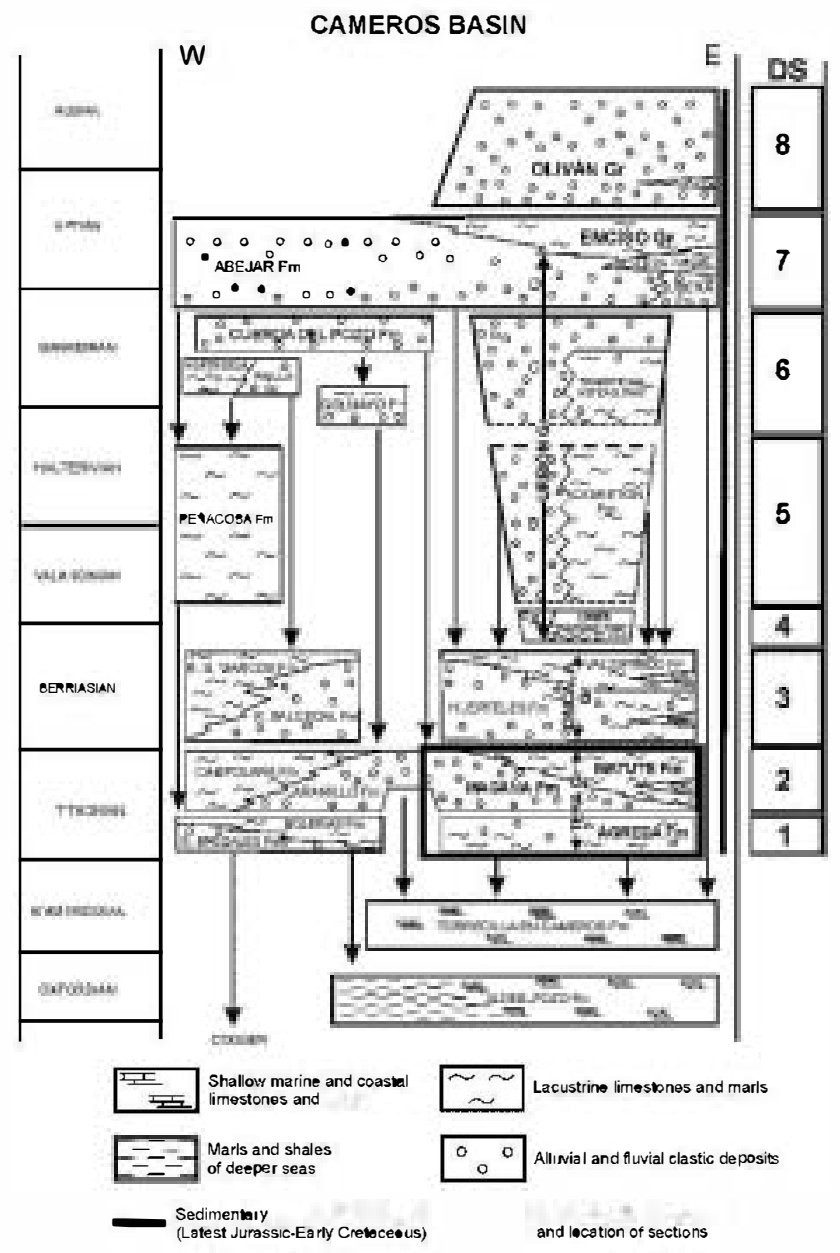

Fig. 2 Stratigraphy of the depositional sequences (DS) of the Cameros Basin. The stratigraphic interval examine is indicated (Tera Group, DS 1 and DS 2). Modified from Mas et al. (2004)

Martín-Cløsas and Aløns-Millán 1998). DS 1 is represented by siliciclastic fluvial fan facies and lacustrine-palustrine carbonate facies. The thickness of DS 1 is highly variable, with maximum thickness of $255 \mathrm{~m}$. DS 2 is thick, up to $1,500 \mathrm{~m}$ in the depocenter, and consists of siliciclastic fluvial facies, which grade upwards and laterally to carbonate lacustrine facies. As in other rifted basins (Evans 1990; Garzanti et a1. 2001, 2003), petrofacies indicate the erøsion -f prerift sedimentary substratum at the beginning of the rifting, f llowed by erosion of the basement in later stages (Arribas et a1. 2003; González-Acebrón et a1.2007), defining a provenance cycle (Arribas et a1. 2007). The sandstones in SAN section show a quartzofeldspathic framew॰rk cœmposition (means: $\mathbf{2}_{83} \mathrm{~F}_{15} \mathrm{Lt}_{2}$ and $\mathbf{Q m}_{85} \mathrm{~K}_{9} \mathrm{P}_{6}$ ), with a dominance of plutonic rock fragments $(\mathrm{Rg}) \bullet v e r$ sedimentary (Rs) and metamorphic rock fragments $(\mathrm{Rm})$ (mean: $\mathrm{Rg}_{37} \mathrm{Rs}_{35} \mathrm{Rm}_{28}$, González-Acebrón et a1.2010). The pøresity reduction of the sandstones occurred mainly by compaction (ICOMPACT $=\mathbf{0 . 9 0}$; Lundergard 1992). Mean framework sandstone composition of the ESP section is $\mathbf{2}_{8 \bullet} \mathrm{F}_{16} \mathrm{Lt}_{4}$ and

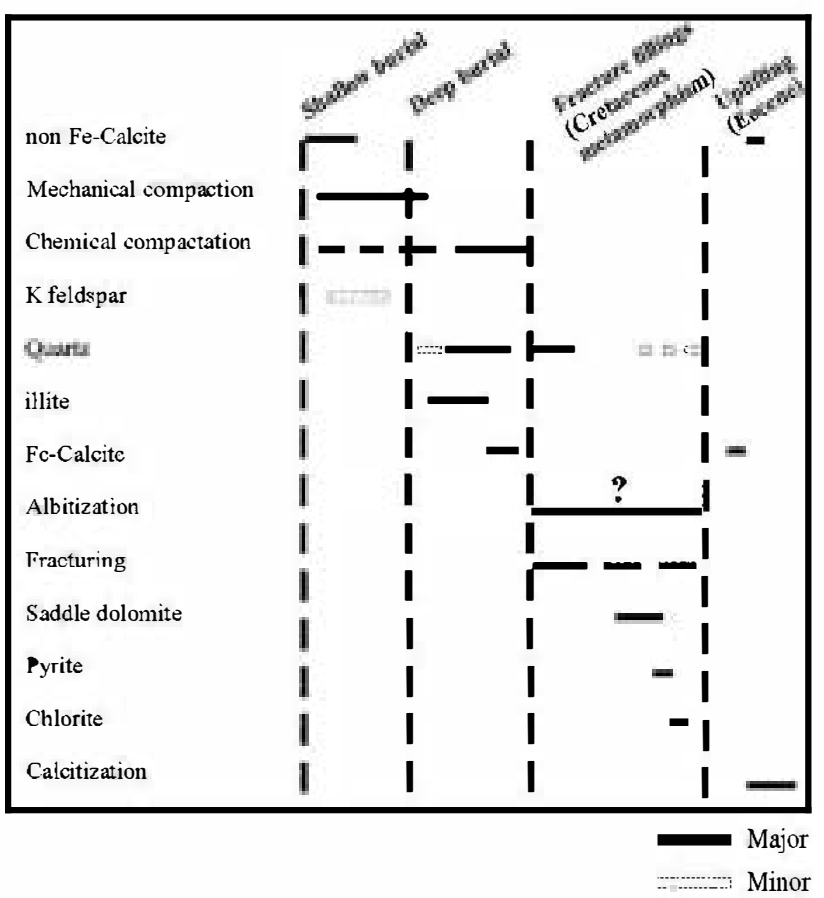

Fig. 3 Sequence of processes and cements in sandstones of ESP and SAN sections. The kaolinite replacement over $\mathrm{K}$-feldspars (epimatrix) has been totally replaced by illite. Muscovite and illite have been partially replace by chlorite. Although the sequence is the same for both sections, the importance of the different diagenetic processes and products is not always the same. Mechanical compaction, calcitized saddle dolomite, pyrite, and chlorite are more abundant in SAN, whereas quartz overgrowth cement is more abundant in ESP record of Rift Stinge 2

$\mathbf{Q m}_{84} \mathrm{~K}_{7} \mathrm{P}$. Plutonic rock fragments $(\mathrm{Rg})$ and sedimentary rock fragments (Rs) are predominant $\left(\mathrm{Rg}_{45} \mathrm{Rs}_{42} \mathrm{Rm}_{13}\right.$, González-Acebrón et a1. 2010). The diagenetic sequence and ICOMPACT is similar to the SAN section (Figs. 3 and 4a), but there is greater develøpment of quartz $\bullet$ vergrowth in the ESP section (Fig. 4b).

\section{Metamørphic prøcesses and studied sectiøns}

During the Late Albian t• Coniacian, hydrothermal alteration affected the deposits of the eastern sector of the Camerøs Basin (Casquet et a1. 1992; Barrenechea et a1. 1995; Aløns•-Azcárate et a1. 1995, 1999, 2002; MantillaFiguer et a1. 1998, 2002). The main features of this thermal alteration are as follows: (1) metamorphic grade is controlled by changes in rock composition and permeability rather than by burial depth (Aløns-Azcárate et al. 1995; Barrenechea et a1. 1995, 2000, 2001); (2) thermal inversions across sections in the depocenter, for example in a single stratigraphic section Valanginian-Barremian deposits of the Urbion Group exhibit a higher metamorphic grade than the Tithonian and Berriasian deposits of Tera and Oncala •lder groups (Mantilla-Figuerøa et a1. 1998, 2002; Barrenechea et a1. 2001); (3) pøstrift age $\bullet$ alteration 

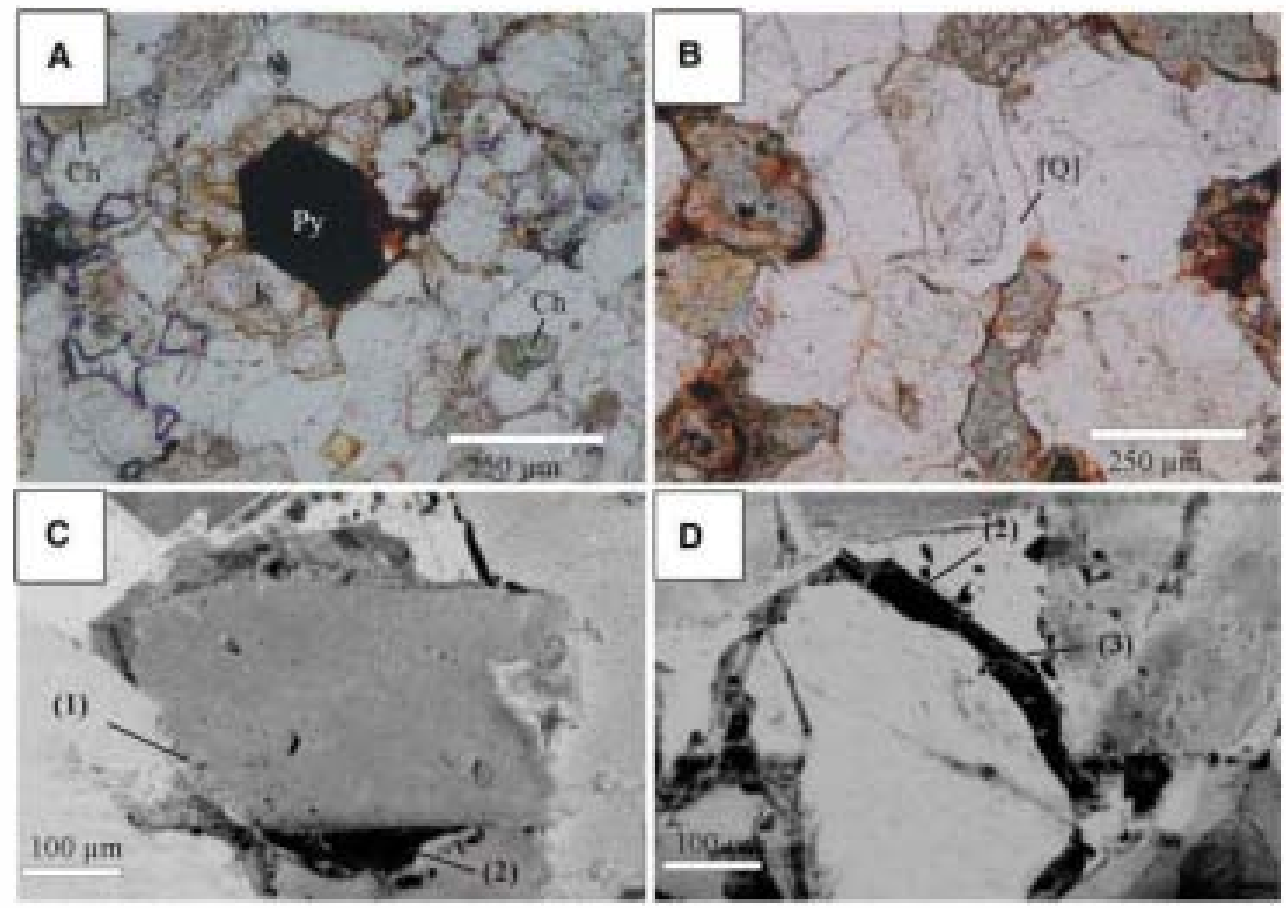

Fig. 4 Perography of ESP section. a Pyrite (Py) replacement of the sandstone framework. Notice the presence of $K$-feldspar $(K)$ and chlorite (Ch). Plane-polarized light. b Quartz overgrowth ([Q]). Plane-polarized light. c Detrital quartz grain and two different quartz syntaxial overgrowths in SEM-CL. Overgrowth (1) is bright luminescent and shows relict fibrous texture. Overgrowth (2) is nonluminescent. Derital quartz grain and two different quartz cements

(Late Albian t• Coniacian, $107 \pm 5$ t॰ $85 \pm 6$ Ma with $\mathrm{K}$-Ar on authigenic illites), after the maximum burial stage, reached during the Early Albian (Casquet et a1. 1992); and (4) metamørphic conditions frøm very løw grade (anchizøne) to low grade (epizone), with temperatures of $350^{\circ}-370^{\circ} \mathrm{C}$ at the metamorphic peak and maximum pressure of $1 \mathrm{kbar}$ (Casquet et a1. 1992; Barrenechea et a1. 1995). Lines of evidence 1 and 2 point to a hydrothermal process rather than the regional metamorphic model suggested by Guiraud and Seguret (1985), Casas-Saínz and Gil-Imaz (1998), and Mata et a1. (2001).

Figure 1 shows the location of the studied stratigraphic sections: SAN and ESP. The Tera Grøup was buried t॰

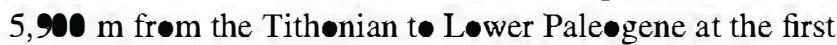
section (SAN). In the second section (ESP), the maximum burial depth for the same stratigraphic interval was prøbably 4,950 m (Gønzález-Acebrón 2009). B॰th burial depths are based on partial restored cross sections from Guimerà et a1. (1995) and Mas et a1. (2003).

The SAN section is located in the metamorphic area of El Pégado anticline (see B in Fig. 1). Illite crystallinity data

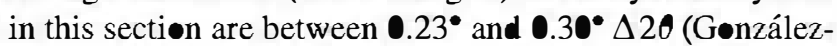
Acebrón 2009). Using the anchizone bøundaries proposed

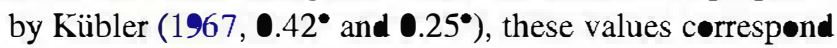

in SEM-CL. Overgrowth (2) is non-luminescent and primary fluid inclusions have Th of $122-128^{\circ} \mathrm{C}$. Overgrowth (3) shows banded luminescence and fills microfractures of the former overgrowth. First stages have Th of $127-128^{\circ} \mathrm{C}$, followe by later fracture fillings with Th reaching $141^{\circ} \mathrm{C}$. Numbers of the overgrowths correspond to the text and Table 5 of electronic supplementary material

to the anchizone-epizone bøundary and are consistent with formerly published data of illite and chlorite crystallinity from the area (Mantilla-Figuerøa 1999; Barrenechea et al. 2001). Mantilla-Figuerøa et al. (2002) recøgnized a secønd very løw-grade metamorphic process in this area as Eøcene $(45 \pm 4 \mathrm{Ma})$ on the basis of radiomeric dating $(\mathrm{K} / \mathrm{Ar})$ on authigenic illites (Mantilla-Figuerøa 1999).

The ESP section is located outside of the zone of metamorphism (Fig. 1). The illite crystallinity data recorded in this section $\left(0.47^{\bullet}-48^{\bullet} \Delta 2 \theta\right.$, González-Acebrón 2009) are typical of diagenetic conditions.

\section{Methods}

Samples were cøllected systematically from tw• representative stratigraphic sections of the Tera Group (SAN and ESP, Fig. 1), rying to represent the vertical variation of the host-rock sandstones (40 samples) and the variety of different minerals $\bullet$ bserved in the field in the fracture fillings (20 samples $\bullet$ fracture fillings; quartz, calcite, chlørite, and pyrite) to establish the paragenesis for host rock and for pøtential conduits for hydrothermal fluid flow. Doubly pølished thick sections were prepared for the samples without 
any heating and glued to frosted glass with cyanøacrilate. After $\bullet$ ptical petrographic analysis of the sections, selected areas $5 \bullet$ them were cut and remøved from the glass using acetone. The microthermomeric study was performed on these portions of samples in a Linkam THMSG-600 heating and freezing stage. The stage was calibrated with synthetic fluid inclusions, including riple pøint of $\mathrm{CO}_{2}$, melting pøint of $\mathrm{H}_{2}$, and critical pøint of $\mathrm{H}_{2}$. Melting pøint of $\mathrm{H}_{2}$ standards shows that the accuracy for low-temperature measurements is better than $\pm 0.1^{\bullet} \mathrm{C}$. Critical point standards show that accuracy for high-temperature measurements is better than $\pm 1.0^{\circ} \mathrm{C}$. Homogenization temperatures (Th) have been interpreted as minimum entrapment temperatures. In this case, no pressure corrections were applied because a pressure determination would inv $\bullet$ lve tø many errør-prøne assumptions withøut an independently •btained value of pressure. The interpretation of Th as minimum entrapment temperatures is a typical procedure in working with Th data

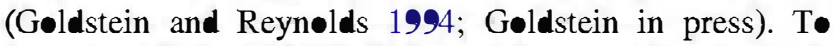
interpret salinity, a $\mathrm{NaCl}-\mathrm{H}_{2}-$ model was used on the basis -f the observed first melting temperatures from fluid inclusions (Bodnar 1993).

Microthermometric and petrographic data were gathered on fluid inclusions in quartz and carbonate fracture fillings from SAN. From ESP, a microthermometric study on quartz overgrowths in sandstones was done. Due to the small size of the quartz overgrowths, this sort of study on quartz cements was not carried out in SAN sandstones. Four selected samples were mounted using aluminum stubs covered by carbon adhesive tape for SEM-CL. Subsequently, they were coated with carbon. Finally, they were studied under CL using a Gatan PanaCL phøt॰multiplierbased CL detector installed on a Le 1550 SEM. The -perating conditions were $12-\mathrm{mm}$ focal distance, $20-\mathrm{kV}$ voltage, and $60-\mu \mathrm{m}$ aperture.

A second group of 9 epøxy-mounted 100 - $\mu$ m-thick sections was prepared for stable is tope study on carbonate-bearing fracture fills from SAN. These sections were etched and stained using Alizarin Red $S$ and potassium ferricyanide for carbonate identification (Lindhølm and Finkelman 1972) after the CL study. Samples were taken using a microdrill and analyzed for $\delta^{13} \mathrm{C}$ and $\delta^{18}$. All sample powders were roasted in vacuum for one hour at $200^{\circ} \mathrm{C}$ to remove volatile organic contaminants and afterward reacted at $73^{\circ} \mathrm{C}$ in an automated carbonate reaction system (Kiel-1) coupled directly to the inlet of a Finnigan MAT 253 gas rati mass spectrømeter. Is $\bullet$ pic rati were collected for ${ }^{17}$ contribution and are reported in per mil notation relative to the VPDB standard. Values were calibrated using NBS 19 as the primary standard. The precision -f the analysis is $\mathbf{0 . 1 \%}$ o for both Oxygen and Carbon. Friedmann and O'Neil (1977) equation has been used for the calculations of $\delta^{18}$ values from temperatures.
Results

Host-rock composition and diagenesis

The host rock of fracture fillings in the SAN section is composed of sandstone (subarkose and orthøquarzite) and lutite, with limestone and marl in the upper part. The diagenesis of the sandstone host rock includes different processes and cements, which have occluded the original porosity. This includes chemical compaction and stylølite formation (Fig. 3). SAN host rock contains pyrite crystals and chlorite nodules, producing a mottled texture and a greenish coloration. Related lacustrine and palustrine limestones are made up of mudstone to wackestone with ostracods and characea. Gypsum pseudomorphs in limestones $\bullet c c u r$ near the top of the section. Lutites and marls are mainly composed of quart $z$, calcite, plagiøclase, illite, and chlorite.

ESP section is composed of sandstones (subarkøse) and minor conglomerates, with limestones and marl in the

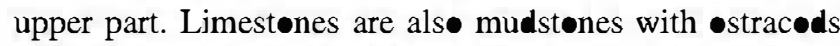
and characea. In the sandstones, at least three different generations of syntaxial quartz overgrowth were identified with SEM-CL, showing primary fluid inclusion assemblages (FIAs) with first melting temperatures near $-28^{\circ} \mathrm{C}$. Clathrates have not been detected.

(1) Bright luminescent overgrowth is the earliest phase and precipitated with relict fibrous texture (1 in Fig. 4c). A primary FIA is identified on the basis of the distribution of the overgrowth, which is consistent with the distribution along the CL bands. The FIA has Th of $114-120^{\circ} \mathrm{C}$ and Tm ice between -10.6 and $-10.3^{\circ} \mathrm{C}$

(2) Non-luminescent syntaxial overgrowth is the second growth phase and contains primary fluid inclusions with distribution consistent with the CL bands (2 in Fig. $4 \mathrm{c}$ and d). A consistent FIA shows Th of $122-128^{\circ} \mathrm{C}$ and $\mathrm{Tm}$ ice of $-12.3 /-11.6^{\circ} \mathrm{C}$.

(3) Banded luminescent quartz cement fills microfractures in the earlier overgrowth (3 in Fig. 4d). First stages have primary fluid inclusions with Th that vary between 127 and $128^{\circ} \mathrm{C}$, f llowed by later fracture fillings with $\mathrm{Th}$ that reach $141^{\circ} \mathrm{C}$ (Tm ice of $-7.8^{\circ} \mathrm{C}$ ) (Table 5 of electronic supplementary material).

Fracture cements

Filled fractures appear in the SAN area and are typically subperpendicular to the stratification and 1 to $50 \mathrm{~cm}$ wide (Fig. 5a). They pinch out or reduce their width in incompetent layers, such as lutites and marls. Main minerals present in these fractures are quartz, ferroan and 

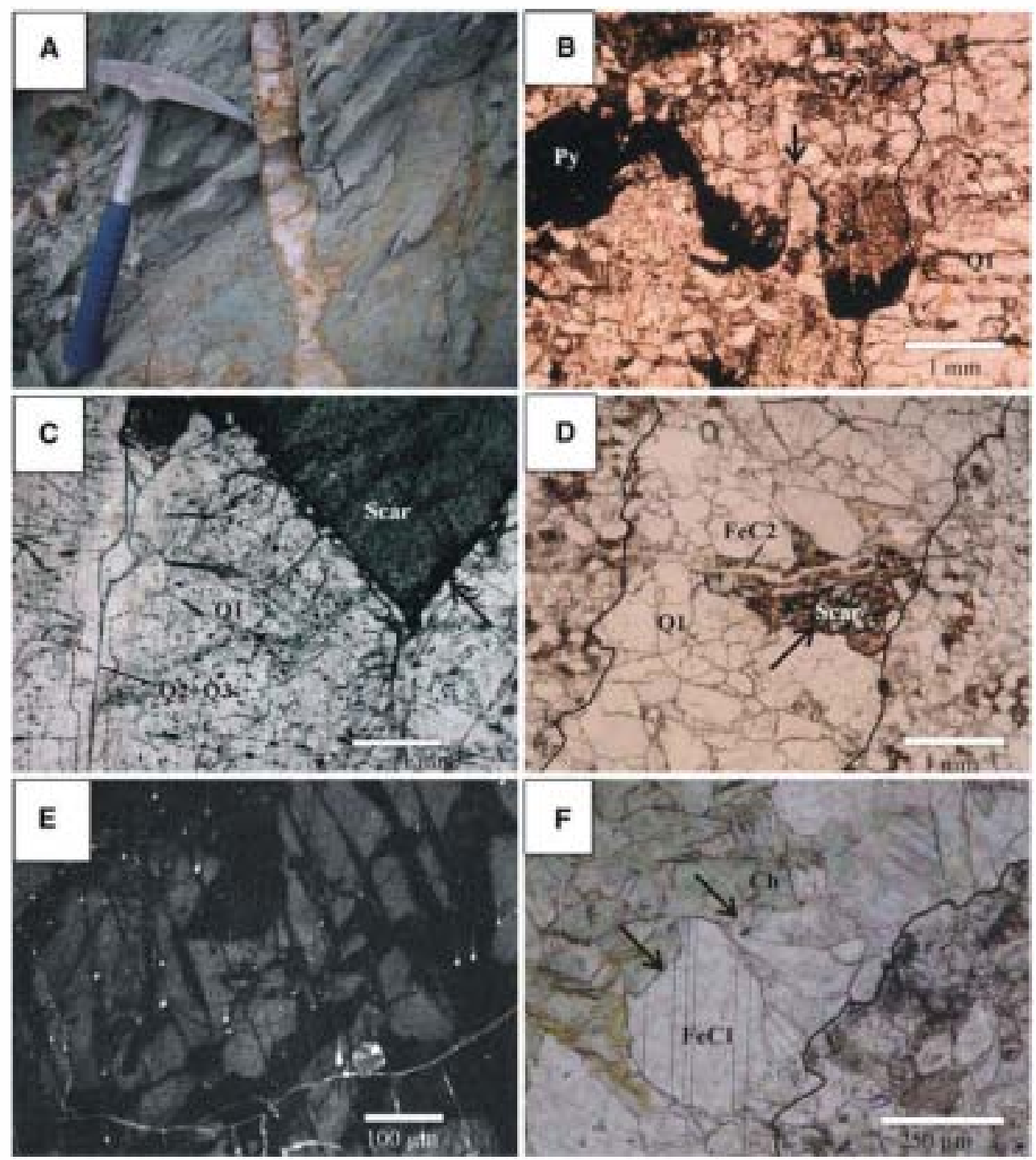

Fig. 5 Perography of the SAN section: a Field aspect of tensional fracture filling in the SAN section (El Pégado anticline). b Quartz vein (1) that postdates the stylolite (arrow). The vein is limited by a line. Py: pyrite. Plane-polarized light. c Two different quartz cements under plane-polarized light. The first one (Q1) corresponds to mottled quartz in SEM-CL (see picture E). The second one $(\mathbf{Q}+\mathbf{Q}$ ) was precipitate after racturing. 2 and $\mathbf{Q} 3$ only can be distinguished under SEM-CL (Fig. 9). The arrow points to the corroded borders of quartz cement at the contact with the saddle carbonate (SCar). The sample was taken from the fracture of photo A (marked area in dotted line refers to Fig. 9). d Sandstone cut by a large fracture (between the lines), first filled with quartz (1) and later filled with saddle

non-ferrøan calcite, chlørite, and pyrite. Rarely, apatite crystals can be observed in thin section.

A common sequence of the fracture fillings was determined using conventional microscopy, CL, and SEM-CL petrography, together with the petrographic and microthermometric study of fluid inclusions (Fig. 6):

(1) Quartz $1(Q 1)$ cement pøstdates styl $\bullet$ lites $\bullet$ the Tera Group sandstones (Fig. Sb). $\mathbf{l} 1$ is hømøgeneøus under

carbonate (SCar). This large fracture is also cut by a small fracture fille with ferroan calcite $(\mathrm{FeC} 2)$. The arrow points to the corroded borders of quartz cement at the contact with the ferroan saddle carbonate. Plane-polarized light. e Mottled texture in quartz cement Q1 (SEM-CL) due to recrystallization associated with the metamorphic peak. A pattern of fracturing can be observed. The image represents an area in photo $\mathrm{C}$. $\mathbf{f}$ Chlorite that postdates the ferroan calcite cement $(\mathrm{FeC} 1)$. The corrosion is marked with arrows. Notice that both appear in a fracture that cut the sandstone framework (right side of the line), and the large size of the chlorite fans. Planepolarized light

ransmitted light microscopy (see 1 in Fig. 5c and d) and shows a mottled texture in SEM-CL (Fig. 5e). Corrosion features are observed in $\mathbf{Q} 1$ where in contact with ferroan saddle dolomite cement (see arrows in Fig. 5c and d).

Q 1 contains primary fluid inclusions of variøus sizes, with orientation and distribution related to growth. Measure fluid inclusions are between 1.5 and $5 \mu \mathrm{m}$ with Th $\bullet$ 
Fig. 6 Sequence of processes and cements of the SAN tensional fracture fillings. Th of fluid inclusions, salinities $(\mathrm{NaCl}$ wt\% $\mathrm{NaCl}$ eq. $), \delta^{18}$ and $\delta^{13} \mathrm{C}$ are shown on one axis. On the other hand, are the different processes, cements, and results listed in order, from older to younger

\begin{tabular}{|c|c|c|c|c|}
\hline \multirow[t]{2}{*}{ Sequence } & Th $\left({ }^{\circ} \mathrm{C}\right)$ & Salinjity & $\delta^{\prime \prime}()$ & \multirow{2}{*}{$\delta^{12} \mathrm{C}$} \\
\hline & $\sqrt{101}$ & $5 \quad 1$ & $h_{1}+1$ & \\
\hline \multicolumn{5}{|l|}{ Stylolites } \\
\hline \multicolumn{5}{|l|}{$\begin{array}{l}\text { Prograde hydrothermal } \\
\text { Q1 }\end{array}$} \\
\hline \multicolumn{5}{|l|}{$\begin{array}{l}\text { Recrystallization of } 01 \\
\text { Metamorphic peak: } 82 \mathrm{Ma} \text {. }\end{array}$} \\
\hline \multicolumn{5}{|l|}{ Cotrosion of 1} \\
\hline \multicolumn{5}{|l|}{ Saddlc ankerite } \\
\hline Ferroan calcite & & & 113:413 & $-7.2 i-7.9$ \\
\hline $\begin{array}{l}\text { Soscontivy FI to ferroan } \\
\text { calcite }\end{array}$ & 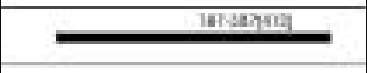 & Antin & & \\
\hline \multicolumn{5}{|l|}{ Ceoling } \\
\hline \multicolumn{5}{|l|}{ Facticatien (Alpine) } \\
\hline \multicolumn{5}{|l|}{ Q2 \& Q3 } \\
\hline 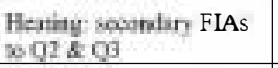 & $\therefore 150$ & 8.0 .79 & & \\
\hline $\begin{array}{l}\text { More heating: secondaty } \\
\text { consistent FIAs }(22 \& \text { Z }\end{array}$ & $281-305$ & $4.7-8.1$ & & \\
\hline $\begin{array}{l}\text { Metaniompte peak: } 40 \mathrm{Ma} \text {, } \\
\text { verrailiteation of Fi }\end{array}$ & $<381$ & 40002 & & \\
\hline \multicolumn{5}{|l|}{ Cooling } \\
\hline Ferroan calcile fracture & & & $\because 1$ & -6.8 \\
\hline $\begin{array}{l}\text { Meteoric waters } \\
\text { calcitization saddle } \\
\text { ankerite }\end{array}$ & $\begin{array}{l}\text { All liquid Fl. Irregular shapes and } \\
\text { different sizes. }<50^{\circ} \mathrm{C}\end{array}$ & & $-8,1-9.0$ & -6.71 .78 \\
\hline $\begin{array}{l}\text { Nonferroan calcite } \\
\text { fracture fillings }\end{array}$ & & & & \\
\hline
\end{tabular}

$5 \mu \mathrm{m}$ decrepitate on the stage during heating, usually at

Primary FLAs $1,2,3,4,5$ Secondary FIA.

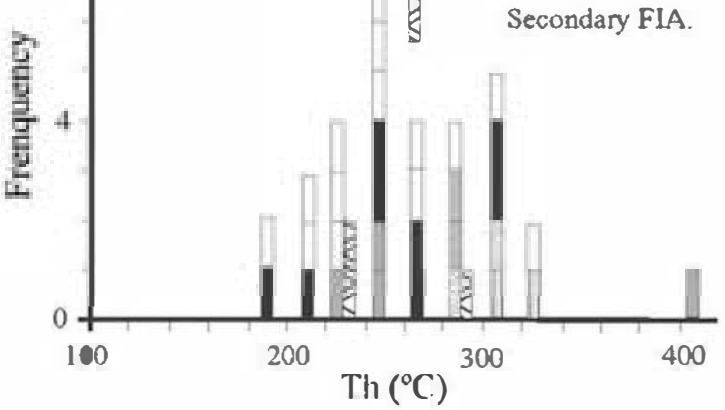

Fig. 7 Frequency histogram of Th of primary fluid inclusions in $\mathbf{Q} 1$ cement (sample 4SAN-27) and some secondary FIA

194.8 and $350.2^{\circ} \mathrm{C}$ (Fig. 7 and Table 1 of electronic supplementary material) and Tm ice between -4.6 and $-3.4^{\bullet} \mathrm{C}$. There is a single outlier with $\mathrm{Th}=402.7-405.8^{\circ} \mathrm{C}$. Th in FIAs are very inconsistent, as $\bullet$ bserved in Fig. 7. N॰

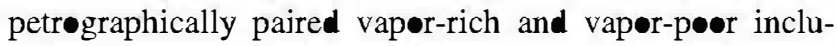
sions were $\bullet$ bserved, indicating that there is n॰ evidence for necking down after a phase change (pinching $\bullet$ ff $\bullet$ single fluid inclusions tø make multiple inclusions). N• vapordominant inclusions were found, evidence against hetergeneous entrapment (e.g. Gøldstein and Reynolds 1994). First melting temperatures (Te) are between -21 and $-19^{\circ} \mathrm{C}$. We $\bullet$ bserved that søe fluid inclusions larger than temperatures higher than $270^{\circ} \mathrm{C}$. The presence of clathrates (gas hydrates) was detected. A vague freezing event -ther than the freezing of the aqueøus phase was detected arøund $-60^{\circ} \mathrm{C}$. In søme fluid inclusions, another freezing event was recorded around $-180^{\circ} \mathrm{C}$.

(2) Saddle carbonate (SCar) postdates 1 (Fig. 5c and d) and exhibits a characteristic saddle habit with curved crystal faces and cleavage and sweeping extinction in cross-pølarized light, as described by Radke and Matthis (1980) and Spötl and Pitman (1998). This nøn-ferrøan calcite contains abundant sølid inclusions

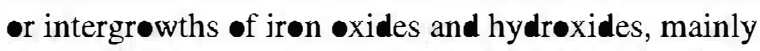
concentated along the cleavage planes.

Tw- different saddle carbonate phases can be distinguished. The earlier one (SCarl) is richer in iron oxide and hydroxide sølid inclusions than the later one (SCar2), indicating twø compositional zones: SCarl. Non-ferrøan calcite, which is non-luminescent in CL, and SCar2. Nonferroan calcite, which is bright luminescent in CL. In places, SCar1 totally have filled small voids and SCar2 only appears in the largest voids $(>1 \mathrm{~mm})$ where enough space was available for its precipitation. Both non-ferroan calcites contain abundant all-liquid fluid inclusions of variable sizes $(2-16 \mu \mathrm{m})$. Stable is topic compositions in both have very similar $\delta^{13} \mathrm{C}$ values between -7.8 and -6.6 (\%o V-PDB) and $\delta^{18}$ values between -9.0 and -8.1 


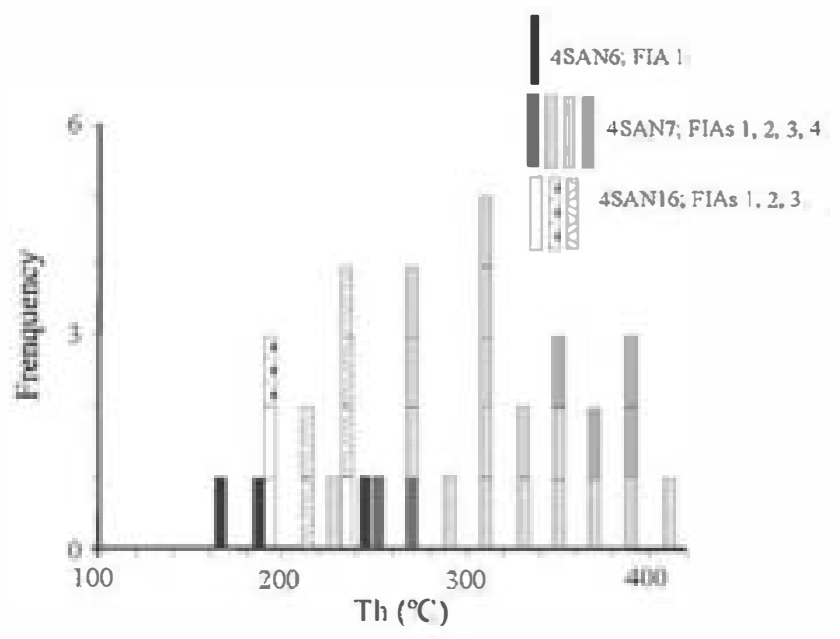

Fig. 8 Frequency histogram of Th of secondary fluid inclusions in ferroan carbonate cements (samples 4SAN-6, 4SAN-7, 4SAN-16)

(\%o V-PDB) in non-luminescent calcite and $\delta^{13} \mathrm{C}$ between -7.4 and -6.6 (\%o V-PDB) and $\delta^{18} 0$ between -9.0 and -8.6 (\% V-PDB) in the brightly luminescent calcite (Table 2 of electronic supplementary material).

(3) Ferroan calcite $(\mathrm{FeCl})$ pøstdates the saddle carbønate (SCar). It normally shows dull luminescence in CL. It contains variably sized fluid inclusions $(2.5-19 \mu \mathrm{m})$. Inclusions are typically secondary with $\mathrm{Th}=168.0-412.7^{\circ} \mathrm{C}$ (Fig. 8 ) and $\mathrm{Tm}$ ice between -5.2 and $-3.7^{\circ} \mathrm{C}$ (Table 3 of electronic supplementary material). Th values in FIAs are very inconsistent (Fig. 7).

Stable is topes have values between -8.9 and -7.2 (\%o V-PDB) for $\delta^{13} \mathrm{C}$ and between -14.3 and -11.8 (\%o VPDB) for $\delta^{18} \bullet$ (Table 2 of electronic supplementary material). The $\delta^{18}$ values are progressively more negative with increasing depth in the section.

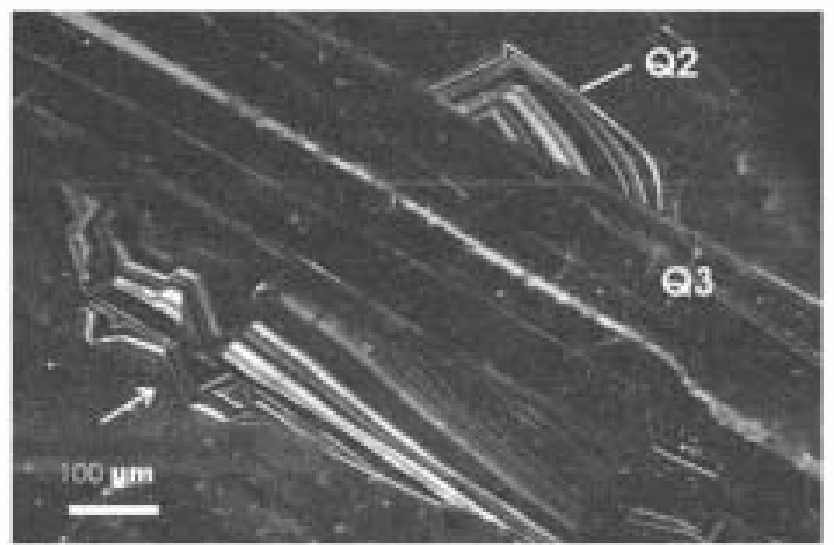

Fig. 9 Two different quartz fracture fillings under SEM-CL. The photograph is taken in the fracture $(\mathbf{Q}+\mathbf{Q})$ of Fig. $4 \mathrm{c}$
(4) Pyrite (Py) crystals appear as part of the fracture fillings and als as replacement $\bullet$ the høst rock. The pyrite typically has cubic shapes and variable sizes (from less than $1 \mathrm{~mm}$ to several centimeters). Quartz and chlorite encrust pyrite crystals where they replace the sandstone framework (Fig. 3). Based on this textural evidence, chlorite postdates pyrite in the fracture fillings.

(5) Chlorite (Ch) postdates and locally corrodes $\mathrm{FeCl}$ (Fig. 5f). It displays green colors and coarse fan morphølogies (100-200 $\mu \mathrm{m})$. It has a magnesiumferroan compesition as has been determined by electron microprøbe analysis.

(6) Quartz 2 (Q2) postdates at least $\mathbf{Q} 1$ and the saddle carbonate (SCar). Q2 fills small fractures that cut the mottled structure of $\mathbf{Q} 1$ (Fig. 9). Thus, a fracturing event is deduced between $\mathbf{Q} 1$ and $\mathbf{Q} 2$. 2 bears primary growth fabrics displaying concentric growth zones of luminescent and non-luminescent quartz as well as søme sector zoning (Fig. 9).

(7) Quartz 3 (Q3) cement cuts $Q 2$ and is a nonluminescent fracture fill (Fig. 9). Under conventional petrography, 2 and 23 look like a single quartz cement phase (Fig. 5c). 3 fills small fractures that postdate $\mathbf{Q} 2$ and can be distinguished in CL. Secondary fluid inclusions in $\mathbf{Q} 2$ and $\mathbf{Q} 3$ show Th -f $281.2-305.2^{\circ} \mathrm{C}$ in søme FIAs with consistent $\mathrm{Th}$, with $\mathrm{Tm}$ ice between $-5.2^{\circ} \mathrm{C}$ and -4.9 (Table 4 of electronic supplementary material and Fig. 10). FIAs with inconsistent Th are als• present, showing Th lower and higher than the consistent ones. Tw॰ different groups can be distinguished: 1. FIAs with lower Th than the consistent FIAs (Th from 150 to

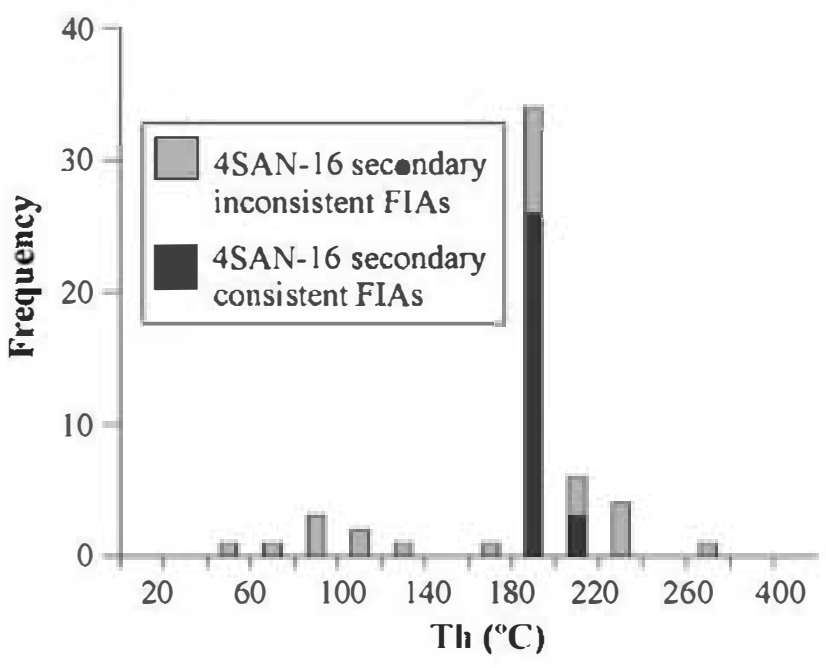

Fig. 10 Frequency histogram of Th of secondary fluid inclusions in Q2 and 23 cements. Notice the distinction between consistent and inconsistent FIAs. Sample 4-SAN-16 
$280^{\circ} \mathrm{C}$ ) and 2. FIAs with higher temperature than the consistent FIAs (Th frøm 305 t॰ $380^{\circ} \mathrm{C}$ ). None of the inclusions in all FIAs shøw petrographic pairing or vapor-rich inclusions. Hence, n॰ evidence of necking down after phase changes or heterøgeneous entrapment was found.

(8) Ferroan calcite ( $\mathrm{FeC2}$ ) cement has filled small fractures $(<2 \mathrm{~mm})$ that cut all the former fracture fillings until chlorite formed. There is no textural evidence that $\mathrm{FeC} 2$ postdates $\mathbf{Q} 2$ and $\mathbf{Q} 3$. Stable is tope compositions of this cement are $\delta^{13} \mathrm{C}=-6.8$ (\%o V-PDB) and $\delta^{18}=-8.1$ (\% V-PDB, Table 2 -f electronic supplementary material).

(9) Non-ferroan calcite $(\mathrm{NFe}$ ) has fille the remaining space reduced by $\mathrm{FeC} 2$. Because of the small size of this cement $(<1 \mathrm{~mm})$, no is topic analyses were performed.

\section{Discussion and interpretation}

Thermal events deduced from fracture fillings

\section{First metamorphic event}

Petrøgraphic characteristics of cements, micrøthermømetry data from fluid inclusions, and isøtopic compositions permit the reconstruction of the sequence of thermal events during fracture filling of the Tera Group (SAN section):

Quartz (Q1) Deduced salinities of $\mathbf{Q} 1$ are between 5.6 and $7.3 \mathrm{wt} \% \mathrm{NaCl}$ eq. Minør amounts of ther ions are alsø likely. $\mathrm{CO}_{2}$ and $\mathrm{CH}_{4}$ are significant components deduced by the clathrate melting events and analyses using Raman micrøprøe on similar inclusions (Mantilla-Figuerøa 1999).

There are several pieces of evidence to relate these primary fluid inclusions t• a hydrøthermal precess:

(A) Th $\left(194.8-350.6^{\circ} \mathrm{C}\right)$ are toe high to be burial temperatures. Assuming a geothermal gradient of $30^{\circ} \mathrm{C} / \mathrm{km}$ (Blackwell 1971; Waples 1980; Hitchon 1984), with a surface temperature of $20^{\circ} \mathrm{C}$, estimated burial temperature at the maximum burial depth would have been no more than $180^{\circ} \mathrm{C}$.

(B) The variability of Th data in each particular fluid inclusion assemblage (Table 1 of electronic supplementary material and Fig. 7) probably is due to natural thermal reequilibration of the fluid inclusions. Qutlier values may indicate the most extreme examples of thermal reequilibration. Stretching and decrepitation are typical processes of fluid inclusions in metamorphic systems (Gøldstein and Reynolds 1994). Alternatively, necking down after a phase change can lead to a few high values, but there is n• perrographic evidence supporting this.

(C) The mottled texture of quartz (Q1) in SEM-CL (Fig. 5e) is interpreted as a recrystallization fabric. The develøpment of this mottled fabric is consistent with the metamorphism interpreted by Casquet et al. (1992) as Cretaceous in age. Recrystallization features of quartz overgrowths previously have been described by Goldstein and Røssi (2002) in sandstones and in hydrothermal veins (e.g., Rush and Reed 2005; Rush et al. 2006).

Saddle carbonate (SCar): The non-ferrean calcite composition of SCar is very likely a replacement of saddle dolomite or ankerite, because these are the typical minerals that form saddle carbonate (Radke and Matthis 1980 and Spötl and Pitman 1998). The all-liquid primary fluid inclusions support recrystallization at low temperature. Similar ankerite cement has been identified by Benit et al. $(2001,2006)$ in the underlying Kimmeridgian limestones, and these authors associated this cement with the Cretaceous hydrothermal metamorphism of the basin followed by low-temperature recrystallization.

Ferroan calcite ( $\mathrm{FeCl}$ ): The deduced salinities in the secondary fluid inclusions of $\mathrm{FeCl}$ are between 6.01 and $8.14 \mathrm{wt} \% \mathrm{NaCl}$ eq. (Fig. 8 and Table 3 of electronic supplementary material). The Th data of secondary fluid inclusions $\bullet \mathrm{FeCl}$ in the same range as the primary fluid inclusions described for quartz (Q1), as well as the high variable Th data, pøint to reequilibration of these secondary fluid inclusions during the Cretaceous metamorphism. In the absence of primary fluid inclusions, stable is tope data are useful in estimating the origin of $\mathrm{FeCl}$. The very negative $\delta^{18} 0$ values are best explained by precipitation at high temperature (around $200-400^{\circ} \mathrm{C}$ ), as the $\mathrm{FeCl}$ postdates $\mathbf{Q}$ and predates chlorite. In addition, the negative values of $\delta^{13} \mathrm{C}$ can be interpreted as being inherited from a system in which waters were derived from an overlaying source probably relate with subaerial exposure that favoured a localized input of highly ${ }^{13} \mathrm{C}$-depleted søil-gas $\mathrm{CO}_{2}$ (Benit• et a1. 2001, 2006).

Pyrite and chlorite: Both the literature and the former established paragenesis suggest that $\mathbf{Q}$ 1, SCar, FeC1, pyrite, and chlorite are metamorphic phases related to the Cretaceøus hydrøthermal event (Alønsø-Azcárate et al. 1999; Mata et a1. 2001; Benit• et a1. 2001, 2006). The large

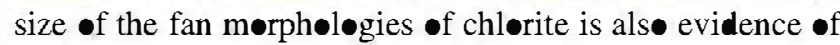
high-temperature growth (Fig. 5f). Thus, primary fluid inclusions of 1 must be related this Cretace thermal alteration. On the basis of CL perrography, the inclusions appear t have been trapped during recrystallization of the Q1 cement. This could indicate that the Cretaceous hydrothermal alteration could have reached temperatures 
-f at least $350-410^{\circ} \mathrm{C}$ (maximum Th of primary fluid inclusions to $\mathbf{Q} 1$ and of secondary fluid inclusions to $\mathrm{FeC} 1$ ).

A post-Cretaceous, second thermal event is interpreted on the basis of radiometric dating (Mantilla-Figuerøa et al. 2002) and has been related to the inversion of the basin during the Eøcene (Alpine Orogeny). Thus, we have to consider the alternative hypothesis that primary fluid inclusions of $\mathbf{Q} 1$ reequilibrated during Eøcene heating. In this case, the inclusions would reflect the conditions of the second thermal event. This hypothesis could be supported by similar salinities between fluid inclusions primary to $\mathbf{Q}$ (5.56-7.31 wt\% $\mathrm{NaCl}$ eq.) and fluid inclusions secondary t• $\mathbf{Q} 2$ and $\mathbf{Q} 3$ (4.73-8.14 wt\% $\mathrm{NaCl}$ eq.).

A Cretaceous age is more likely, however, because n॰ consistent FIAs were found in $\mathbf{Q} 1$ which exhibits recrystallized textures. These $\bullet$ bservations suggest that a thermal maximum may have been reached during the Cretaceous hydrothermalism and that this thermal process was responsible for the reequilibration of primary inclusions and recrystallization in $\mathbf{Q}$.

The steep thermal gradient as a consequence -f hydrothermal prøcesses

The similar petrographic character, paragenesis, and chemical composition of $\mathrm{FeCl}$ in all fracture fillings allow us to assume same or similar age and fluid composition for $\mathrm{FeCl}$ throughout the studied section. Given the same fluid is otopic composition precipitating $\mathrm{FeCl}$ throughout the section, the upward increase in $\delta^{18}$ indicates a steep paleogeothermal gradient. The maximum difference in vertical stratigraphic position between analyzed samples is $370 \mathrm{~m}$. The paleotemperatures have been calculated for tw॰ possible scenarios: (1) in which the sediment with the deepest burial precipitate at $200^{\circ} \mathrm{C}$ and (2) a deep burial precipitation temperature of $300^{\circ} \mathrm{C}$. These temperatures were chosen because $200^{\circ} \mathrm{C}$ is close to the lowest temperature of primary fluid inclusions of $\mathbf{Q}\left(194.8^{\circ} \mathrm{C}\right)$ and $300^{\circ} \mathrm{C}$ is close to the highest temperature of these fluid inclusions $\left(350.6^{\circ} \mathrm{C}\right)$. Given the first scenari $\left(200^{\circ} \mathrm{C}\right)$, the data indicate a metamorphic gradient of $153^{\circ} \mathrm{C} / \mathrm{km}$ in the lower part and $72^{\circ} \mathrm{C} / \mathrm{km}$ in the upper part of the section (Fig. 11). Given the second scenariv $\left(300^{\circ} \mathrm{C}\right)$, the data indicate a gradient of $276^{\circ} \mathrm{C} / \mathrm{km}$ in the lower part and $121^{\circ} \mathrm{C} / \mathrm{km}$ in the upper part of the section (Fig. 11). This steep and decreasing gradient from the bottom to the top is probably due to a rapid injection of hot fluids into cooler rocks, associated with hydrothermal processes. The calculated values of $\delta^{18}$ of the water are between 6.5 and 13.0 (\%o V-SMOW) for the proposed temperatures (300 and $200^{\circ} \mathrm{C}$, respectively). These are typical values of metamorphic waters (Taylor 1974). A similarly high geothermal

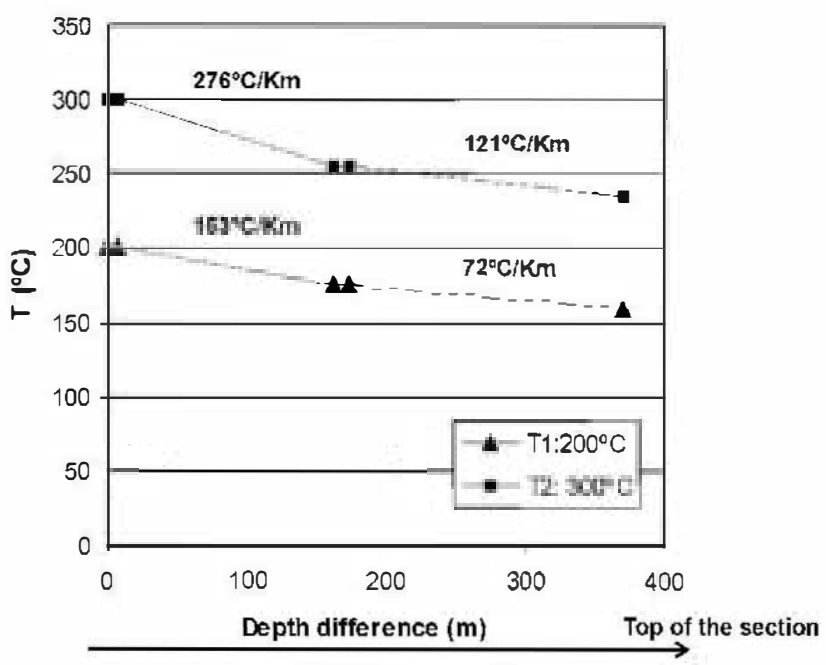

Fig. 11 Paleogeothermal gradient recorded using $\delta^{18}$ values of the FeC1 in 5 samples of different burial depth of the SAN section. The $x$ axis indicates the depth difference among samples. Notice the decrease in the gradient to the top of the section

gradient is recorded for the Cobre-Babilonia hydrothermal vein system $\left(170-200^{\circ} \mathrm{C} / \mathrm{km}\right)$ by Camprubí et al. (2006).

\section{Second metamorphic event}

Quartz (Q2 and Q3): Consistent Th values ( $\mathrm{Th}=$ $281.2-305.2^{\circ} \mathrm{C}$ ) in secondary FIAs in $\mathbf{Q} 2$ and $\mathbf{Q} 3$ can be related either t• (1) a retrograde stage of Cretace us hydrothermalism or to (2) a later event of thermal alteration. We consider the second possibility more likely for the following reasons: (1) the saddle dolomite or ankerite precipitated between the mottled quartz cement $(\mathbf{Q} 1)$ and the two different quartz stages (Q2 and Q3) that fill the later fractures; (2) FIAs are not reequilibrated; thus, they prøbably have not experienced much •verheating after their entrapment; (3) the FIAs pøstate the recrystallization of quartz, which may have been associated with the Cretaceous metamørphism.

Q2 and Q3 may postdate the Cretaceous metamorphism because quartz has nøt recrystallized. The lower Th of the consistent FIAs in $\mathbf{Q} 2$ and $\mathbf{Q} 3$ compared to $\mathbf{Q} 1$ Th indicate that the thermal peak was reached before entrapment of the FIAs in Q2 and Q3. High temperatures in these secondary inclusions, higher than would normally be ascribed to burial, could be indicative of their entrapment during the late (cooling) stages of Cretaceous hydrothermalism or during Eocene hydrothermalism. Deduced temperatures using chlorite microthermometry for the Eocene alteration (Mantilla-Figuerea et al. 2002) are in the same range $\left(290^{\circ} \mathrm{C}\right)$ as fluid inclusion $\operatorname{Th}\left(281.2-305.2^{\circ} \mathrm{C}\right)$. Thus, we consider the Eocene hypothesis more probable. Lower Th FIAs $\left(150-280^{\circ} \mathrm{C}\right)$ were probably trapped earlier and the 
higher Th FIAs $\left(305-380^{\circ} \mathrm{C}\right)$ trapped later. The increasing temperatures would cause thermal reequilibration of lower temperature fluid inclusions.

\section{Later processes}

Ferroun and non-ferroan calcite ( $\mathrm{FeC} 2$ and $\mathrm{NFeC}$ ): Last fracture fillings are probably related to the alpine contraction influx of meteric waters. Meteric waters are alsø responsible for the calcitization of the saddle dolomite or ankerite. Evidence of recrystallization due to meteoric water is:

(1) All-liquid fluid inclusions entrapped during recrystallization indicate that the calcitization process probably was below about $50^{\circ} \mathrm{C}$ following Gøldstein and Reynølds' (1994) criteria.

(2) Non-ferroan composition of NFeC and the presence of sølid inclusions of ferrøan oxides and hydroxides in the $\mathrm{NFeC}$ are related to the original phase of precipitation (saddle dolømite or ankerite).

(3) The negative $\delta^{18}$ values for SCarl and SCar2, due to replacement by non-ferrøan calcite, are similar t॰ what would be expected for calcite precipitation from a low-temperature fluid with $\delta^{18} \bullet$ of the present-day grøundwater (-9.5 t• -9.1\%, V-SM○W, Plata 1994) with median temperatures of $13^{\circ} \mathrm{C}$ (Spanish Geølogical Survey, unpublished data). Calcite precipitating under these conditions would have a $\delta^{18} 0$ of -9.4 to $-9.8 \%$.

(4) The relatively invariant values for the $\delta^{18} 0$ and the negative values for the $\delta^{13} \mathrm{C}$ are typical of meteoric diagenesis (Allan and Mattews 1982; James and Chøquette 1990).

The very similar is topic values for SCar1 and SCar2 (Table 2 of electronic supplementary material) indicate that they were probably recrystallized by a similar low-temperature meteoric fluid. Figure 12 resumes the diagenetic and metamorphic evolution of a hypothetical sandstone sample •f the Tera Grøup in SAN section in relation tø the basin development.

Difference between fracture fills and høst røck

Evidence for a lack of equilibrium between the høst røck and the high temperatures in fracture fillings is important in constraining the thermal alteration as hydrothermal. The lack of equilibrium indicates that hot fluids were focused along fractures. Minimum fluid inclusion-based temperatures in fractures reache $400^{\circ} \mathrm{C}$, whereas the $\mathrm{X}$-ray diffraction data from lutites in the host rock point to lower temperatures (anchizone-epizone boundary: MantillaFiguerøa 1999; Barrenechea et a1. 2001). This difference is prøbably related the low permeability $\bullet$ f the høst røck at the møment $\bullet$ the Cretace $\bullet$ us hydrothermal alteration, and f $\bullet$ cus fluids aløng fractures, leading t॰ different thermal histories in host rock versus fractures, or short-lived fluid flow that did not allow equilibration of the høst røck.

Quartz diagenesis in the høst røck

The ESP section preserves a record of sandstone diagenesis in an area lacking evidence for major hydrothermal alteration. Clathrates have not been detected, indicating lower gas contents than fluid inclusions measured from the SAN area. Fluid inclusions in the syntaxial quartz overgrowths indicate precipitation during progressive burial frøm highsalinity fluids generating the following sequence:

(1) Bright luminescent quartz overgrowth (see number 1 in Fig. 4c) interpreted as a pseudomorphic replacement of chalcedony or søme less stable silica precursor based on its relict fibrous texture (e.g. Gøldstein and Røssi 2002). Assuming a geothermal gradient of $30^{\circ} \mathrm{C} / \mathrm{km}$, Th of this cement implies the burial depths of at least 3,100-3,300 m, consistent with a late Barremian-early Aptian age or later, based on the reconstructions of Mas et a1. (2002, 2003). Salinities from $\mathrm{Tm}$ ice measurements are between 14.3 and 14.6 wt\% $\mathrm{NaCl}$ eq. (Table 5 of electronic supplementary material).

(2) Non-luminescent quartz overgrowth (see number 2 in Fig. 4c and d, Table 5 of electronic supplementary material) suggests by its Th a burial depth of at least 3,400-3,600 m, consistent with a late Aptian-early Albian age $\bullet$ later, based on the reconstructions of Mas et a1. (2002, 2003). Thus, syntaxial quartz -vergrowths (1) and (2) are most easily interpreted as predating Cretaceous thermal alteration (late Albian-Coniacian). Salinities from Tm ice measurements of phase 2 FIAs are between 15.8 and 16.2 wt\% $\mathrm{NaCl}$ eq.

(3) Banded luminescent quartz cement (see number 3 in Fig. 4d) is probably relate to a deeper burial than the FIAs of stage 2, because it postdates quartz cement phases (1) and (2) and has higher Th. Salinities from Tm ice measurements are between 11.5 and $12.1 \mathrm{wt} \%$ $\mathrm{NaCl}$ eq.

Temperature data from ESP syntaxial cements prøbably predate temperature data from fracture fillings at SAN, because fracture fillings cut quartz syntaxial $\bullet$ vergrewths. The influence of major hydrothermal processes has not been recorded at ESP, as pointed out by the illite crystallinity (diagenetic field, González-Acebrón 2009) and fluid inclusion micrøthermometry. As far as the lithøløgies and age of the høst røcks are equivalent in bøth sectiøns, this 
Fig. 12 Geological sketch for the diagenetic and metamorphic evolution of a hypothetical sandswe sample of the Tera Group in SAN (Magaña Fm, DS 2)
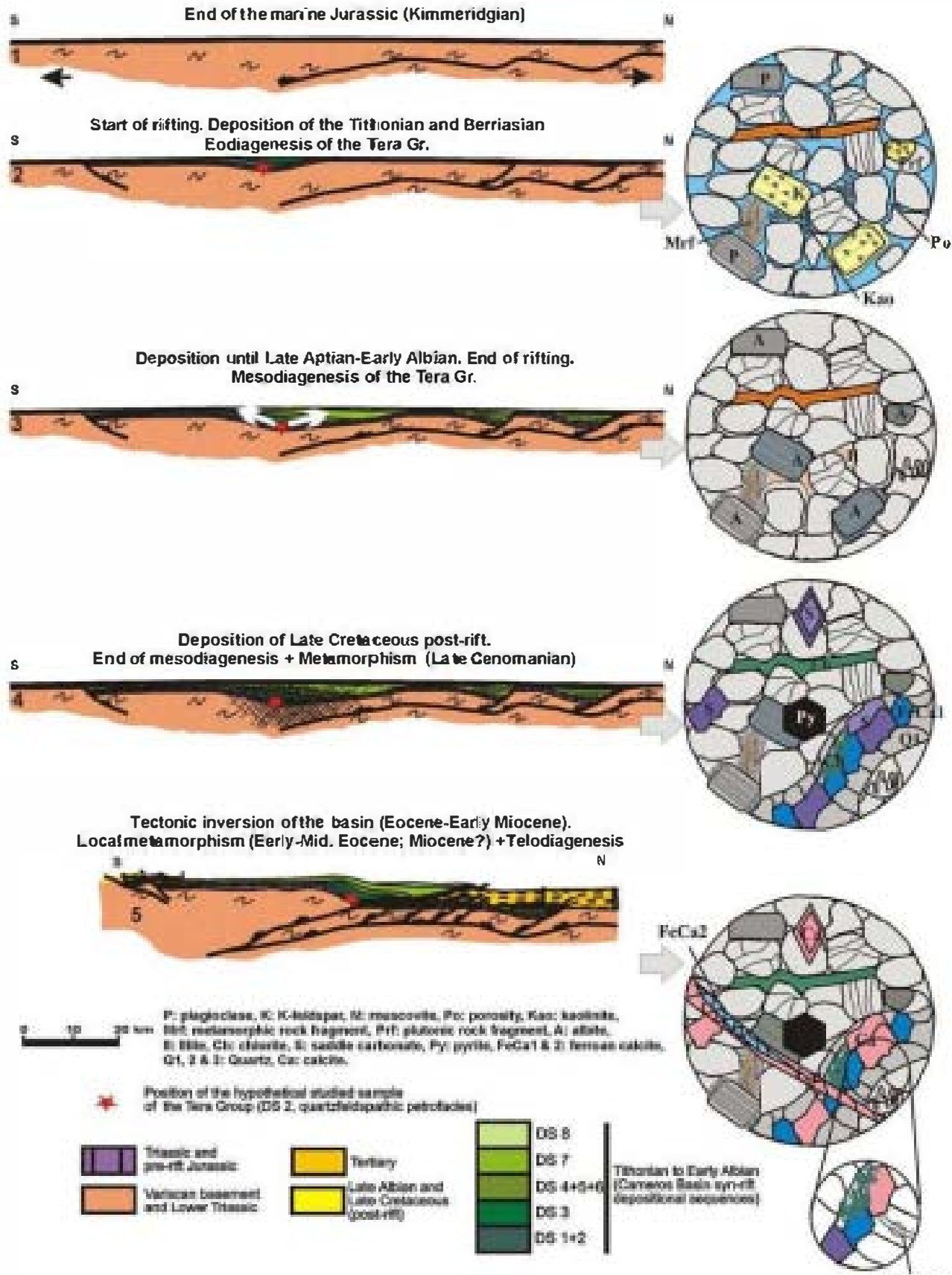

Q28:03 work confirms the local nature of hydrothermal alteration as independent of the burial history.

\section{Conclusions}

(1) The effects of different metamorphic events can been recognized in the same fracure fullings, based on detailed petrography, stable isotopes, and microthermometry of fluid inclusions. Fluid inclusions combined with SEM-CL are the essential tool, in this case, to help delineate the thermal history of very low-grade to low-grade metamerphism from hydrothermal alteration. The fact that fluid inclusion assemblages typically partially reequilibrate during metamerphism aids in the determination of thermal history.

(2) Evidence of quartz recrystallization has been found using SEM-CL in syntaxial vergrowths and fracture fillings, related to very low-grade to low-grade 
metamorphism. They include fibrous textures from a less stable silica precursør, mottled texture, and reequilibrated Th from fluid inclusions. At least three different quartz fracture fillings separated by two fracturing events have been recognized in the same fracture using SEM-CL. Despite recrystallization and multiple events of quartz precipitation, aspects of thermal history in these metamorphic systems can be discriminated.

(3) Stable is topic data are used to show that a steep geothermal gradient of $153-276^{\circ} \mathrm{C} / \mathrm{km}$ in the lower stratigraphic intervals decreased upward to $72-121^{\circ} \mathrm{C} / \mathrm{km}$ in the upper stratigraphic intervals. Such abnormal gradients are one hallmark of hydrøthermal fluid flow, and changes in gradient can help to delineate pathways of fluid flow.

(4) One Cretaceous as well as one Eøcene event of hydrothermal alteration can be discriminated on the basis of radiømetric dating, petrographic relatiønships, and fluid inclusion data. This approach for discriminating between different thermal events has widespread applicability in systems where timing and origin of multiple thermal events are normally not routinely discriminated. Our research should encourage other researchers that this discrimination is possible.

(5) High paleotemperatures in fracture fillings in the Tera Grøup are out of equilibrium with host rock (illite crystallinity data). These differences are probably due to the low permeability of the host-rock and shortterm hydrothermal fluid flow through fractures. This lack of equilibrium between fracture-fill paleotemperatures and host-rock paleotemperatures is strong evidence of hydrothermal alteration and preferential focus of fluids thrøugh fractures. Similar comparisøns can be made elsewhere, in other metamorphic systems, to discriminate between hydrothermal and other forms of heating.

Acknowledgments Funding for this research was provided by the Spanish DIGICYT projects BTE 2001-026, CGL 2005-07445-C0302/BTE and CGL2008-01648/BTE, and by UCM-CM (Universidad Complutense-Madrid Community) for the Research Group "Sedimentary Basin Analysis" for the present contract of the first author. The authors would like to thank Barrenechea, J.F. and Rankey, E. for their useful suggestions and Shinonge, H., Cane, G., Herrero, G., Moral, B., and Barajas, M.A. for their technical support. This manuscript benefits by the useful comments of C. Augustsson and an anonymous referee.

\section{References}

Allan AR, Mattews RK (1982) Isotope signatures associated with early meteoric diagenesis. Sedimentology 29:797-817
Alonso-Azcárate J, Barrenechea JF, Rodas M, Mas R (1995) Comparative study of the transition between very low-grade metamorphism and low-grade metamorphism in siliciclastic and carbonate sediments. Early Cretaceous, Cameros Basin (North Spain). Clay Miner 30:407-419

Alonso-Azcárate J, Rodas M, Botrell SH, Raiswell R, Velasco F, Mas $\mathbf{R}$ (1999) Pathways and distances of fluid flow during lowgrade metamorphism: evidence from pyrite deposits of the Cameros Basin, Spain. J Metamor Geo1 17(4):339-348

Alonso-Azcárate J, Rodas M, Botrell SH, Mas R (2002) Los yacimientos de pirita de la Cuenca de Cameros, Zubía. Instituto de Estudios Riojanos 14:173-190

Arribas J, Alonso A, Mas R, Tortosa A, Rodas M, Barrenechea JF, Alonso-Azcarate J, Artigas R (2003) Sandstone petrography of continental depositional sequences of an intraplate rift basin: Western Cameros Basin (North Spain). J Sediment Res 73(2):309-327

Arribas J, @choa M, Mas R, Arribas ME, González-Acebrón L (2007) Sandstone petrofacies in the northwestern sector of the Iberian Basin. J Iberian Geol 33(2):191-206

Barrenechea FJ, Rodas M, Mas JR (1995) Clay mineral variation associate to diagenesis and low-grade metamorphism of early Cretaceous sediments in the Cameros Basin, Spain. Clay Miner 30:89-103

Barrenechea FJ, Rodas M, Frey M, Alonso-Azcárate J, Mas JR (2000) Chlorite, Corrensite and Chlorite- Mica in Late Jurassic FluvioLacustrine sediments of the Cameros Basin of Northeastem Spain. Clay Clay Miner 48(2):256-265

Barrenechea FJ, Rodas M, Frey M, Alonso-Azcárate J, Mas JR (2001) Clay diagenesis and low-grade metamorphism of Tithonian and Berriasian sediments in the Cameros Basin. Clay Miner 36(3):325-333

Benito MI, Lolımann KC, Mas R (2001) Discrimination of multiple episodes of meteoric diagenesis in a Kimmeridgian reefal complex, north Iberian Range, Spain. J Sediment Res 71(3):380-393

Benito MI, Lohmann KC, Mas R (2006) Micro-sized dolomite inclusions in ferroan calcite cements developed during burial diagenesis of Kimmeridgian reefs, Northem Iberian Basin, Spain. J Sediment Res 76:472-482

Bjorlykke K (1998) Clay mineral diagenesis in sedimentary basins-a key to the prediction of rock properties. Examples from the North Sea Basin. Clay Miner 33:15-34

Blackwell DD (1971) The thermal structure of the continental crust. In: Heacock JG (ed) The structure and physical properties of the earth's crust. Geophysical Monograph 14, pp 169-184

Bodnar RJ (1993) Revised equation and Table for determining the freezing point depression of $\mathrm{H} 2-\mathrm{NaCl}$ solutions. Geochim Cosmochim Acta 57:683-684

Camprubí A, González-Partida E, Torres-Tafolla E (2006) Fluid inclusions and sTable isotope study of the Cobre-Babilonia polymetallic epithermal vein system, Taxco district, Guerrero, Mexico. J Geochem Exp 89:33-38

Casas-Sáinz AM, Simón-Gómez JL (1992) Stress field and thrust kinematics: a model for the tectonic inversion of the Eastern Cameros Basin, Northem Spain. Geol Rudsch 86:802-818

Casas-Saínz AM, Gil-Imaz A (1998) Extensional subsidence, conractional folding and thrust inversion of the Eastem Cameros Basin, Northern Spain. Geol Rudsch 86:802-818

Casas-Saínz AM, Villalaín JJ, Soto R, Gil-Imaz A, Del Río P, Fernández G (2009) Multidisciplinary approach to an extensional syncline model for the Mesozoic Cameros Basin (N Spain). Tectonophys 470:3-20

Casquet C, Galindo C, González-Casado JM, Alonso A, Mas R, Rodas M, García E, Barrenechea JF (1992) E1 metamorfismo en la Cuenca de Los Cameros. Geocronología e implicaciones tectónicas. Geogaceta 11:22-25 
Coveney RM Jr, Ragan VM, Brannon JC (2000) Temporal benchmarks for modeling Phanerozoic flow of basinal brines and hydrocarbons in the southerm midcontinent based on radiometrically dated calcite. Geol 28:795-798

Davies GR, Smith T (2006) Structurally controlled hydrothermal dolomite reservoir facies: an overview. AAPG Bull 90:1641-1690

De Caritat P, Hutcheon I, Walshe J (1993) Chlorite geothermometry: a review. Clay Clay Miner 41:219-239

Del Río P, Barbero L, Mata P, Fanning CM (2009) Timing of diagenesis and very low-grade metamorphism in the eastem sector of the Sierra de Cameros (Iberian Range, Spain): a U-Pb SHRIMP study on monazite. Terra Nova 21:438-444

Essene EJ, Peacor DR (1995) Clay mineral thermometry: a critical perspective. Clay Clay Miner 43:540-553

Essene EJ, Peacor DR (1997) llite and smectite: metastable, stable, or unstable? Further discussion and a correction. Clay Clay Miner 45:116-122

Esteban M, Taberner C (2003) Secondary porosity development during late burial in carbonate reservoirs as a result of mixing and/or cooling brines. J Geochem Explor 78-79:355-359

Evans AL (1990) Miocene sandstone provenance relations in the Gulf of Suez: insights into Synrift unroofing and uplift history. AAPG Bull 74:1386-1400

Friedmann EI, O'Neil JR (1977) Compilation of stable isotope fractionation factors of geochemical interest. In: Fleischer M (ed) Data of geochemistry, 6 edn. Geol Surv Profes Pap 440-KK. 85 p

Garzanti E, Vezzoli G, Andò S, Castiglioni G (2001) Perology of Rifte-Margin sand (Red Sea and Gulf of Aden, Yemen). J Geol 109:277-297

Garzanti E, Vezzoli G, Andò S, Dell'Era D (2003) From rifted margins to foreland basins: investigating provenance and sediment dispersal across desert Arabia (Mman, UAE). J Sediment Res 73(4):572-588

Golber JM, Guiraud M, Maluski H, Seguret M (1988) Caractéres petrologiques êtage du métamorphisme en contexte distensive du bassin sur décrochement de Soria (Crétacé Inferiour, Nord Espagne). C R Acad Sci París, Serie II 307:521-527

Goldstein RH (in press) Fluid inclusion geothermomery in sedimentary systems: from paleoclimate to hydrothermal. In: Harris $\mathbf{N}$ (ed) SEPM special publication, Thermal History Analysis of Sedimentary Basins

Goldstein RH, Reynolds TJ (1994) Systematics of fluid inclusions in diagenetic minerals. SEMP Short Course $31.192 \mathrm{p}$

Goldstein RH, Rossi C (2002) Recrystallization in quartz overgrowths. J Sediment Res 72(3):432-440

Gómez-Fernández JC, Meléndez N (1994) Estratigrafía de la Cuenca de los Cameros (Cordillera Ibérica Noroccidental, N de Espan̄a) durante el ránsito Jurásico- Cretácico. Rev Soc Geol Esp $7(1-2): 121-139$

González-Acebrón L (2009) The Tera Group in the Eastern sector of the Cameros Basin: sedimentary environments, provenance and diagenetic evolution. Dissertation, Universidad Complutense de Madrid, p 424

González-Acebrón L, Arribas J, Mas R (2007) Provenance of fluvial sandstones at the start of late Jurassic-early Cretaceous rifting in the Cameros Basin (N. Spain). Sediment Geol 202:138-157

González-Acebrón L, Arribas J, Mas R (2010) Sand provenance and implications for paleodrainage in a rift basin: the Tera Group. J Iberian Geol 36(1):179-184

Guimerà J, Alonso A, Mas JR (1995) Inversion of an exextensionalramp basin by a newly formed thrust: the Cameros Basin (N Spain). In: Buchanan, JG, Buchanan PG (eds) Basin inversion. Geol Soc Spec Publ 88, pp 433-453

Guimerà J, Mas JR, Alonso A (2004) Intraplate deformation in the NW Iberian Chain: Mesozoic extension and Tertiary contractional inversion. J Geol Soc London 161:291-303
Guiraud M, Seguret M (1985) A realising solitary overstep model for the late Jurassic- Early Cretaceous (Wealdian) Soria strike-slip basin (Northern Spain). SEMP Spec Pub1 37:159-175

Hiemstra EJ, Goldstein RH (2005) The diagenesis and fluid migration history of the Indian Basin Field, Eddy County, New Mexico, In: Lufholm P, Cox D (eds) Unconventional reservoirs, technologies, and strategies, new perspectives for the permian basin. WTGS Publication 05-115, pp 197-206

Hitchon B (1984) Geothermal gradients, hydrodynamics, and hydrocarbon occurrences, Alberta, Canada. AAPG Bull 68(6):713-743

James NP, Choquette PW (1990) Limestones- The meteoric diagenetic environment. In: McIlreath IA, Morrow DW (eds) Diagenesis. Geosci Can, Reprint series, 4, pp 35-73

Kübler B (1967) La cristalinité de l'illite et les zones tout à fait supérieures du métamorphisme. Etages Tectoniques. Coll. Neuchâtel 105-122

Lacazette A (1990) Application of linear elastic fracture mechanics to the quantitative evaluation of fluid-inclusion decrepitation. Geol 18:782-785

Lindhohn RC, Finkehnan RB (1972) Calcite staining: semiquantitaive determination of ferrous iron. J Sediment Perol 42:239-245

Lundergard PD (1992) Sandstone porosity loss. A "big picture" view of the importance of Compactation. J Sediment Petrol 62:250-260

Machel HG, Lonnee J (2002) Hydrothermal dolomite--A product of poor definition and imagination. Sed Geol 152:163-171

Mantilla-Figueroa LC (1999) E1 metamorfismo hidrotermal de la sierra de Cameros (La Rioja-España): Petrología, geoquímica, geocronología y contexto estructural de los procesos de interacción fluido-roca. Dissertation, Universidad Complutense de Madrid, p 361

Mantilla-Figueroa LC, Casquet C, Mas JR (1998) Los paleofluidos del Grupo Oncala, Cuenca de Cameros (La Rioja, España): Datos de inclusiones fluidas, isótopos de oxígeno y SEM. Geogaceta 24:207-210

Mantilla-Figueroa LC, Casquet C, Galindo C, Mas JR (2002) El metamorfismo hidrotermal Cretácico y Paleógeno de la Cuenca de Cameros (Coordillera Ibérica, España). Zubía. Instituto de Estudios Riojanos 14:143-154

Martín-Closas M, Alonso-Millán A (1998) Estratigrafia y Bioestratigrafía (Charophyta) del Cretácico inferior en el sector occidental de la Cuenca de Cameros (Cordillera Ibérica). Rev Soc Geol Esp 11:253-269

Mas R, Alonso A, Guimerà J (1993) Evolución tectonosedimentaria de una cuenca extensional in raplaca: la cuenca finijurásicaeocretácica de Los Cameros (La Rioja- Soria). Rev Soc Geol Esp 6(3-4):129-144

Mas R, Benito MI, Arribas J, Serrano A, Guimerà J, Alonso A, Alonso-Azcárate J (2002) La Cuenca de Cameros: desde la extensión finijurásica-eocretácica a la inversión terciariaimplicaciones en la exploración de hidrocarburos. Zubía. Instituto de Estudios Riojanos 14:9-64

Mas R, Benito MI, Arribas J, Serrano A, Guimerà J, Alonso A, Alonso-Azcárate J (2003) The Cameros Basin: From late Jurassic- early Cretaceous Extension to Tertiary contractional inversion- implications of hydrocarbon exploration. In: AAPG international conference and exhibition, Barcelona, Spain. Geological Field Trip, vol 11. $52 \mathrm{p}$

Mas R, García A, Salas R, Meléndez A, Alonso A, Aurell M, Bádenas B, Benito MI, Carenas B, García-Hidalgo JF, Gil J, Segura M (2004) 5.3.3. Segunda fase de rifting: Jurásico Superior-Cretácico Inferior. In: Vera J (ed) Geología de España, Soc Geol EspIGME, 503-509

Mata MP, Casas AM, Canals A, Gil A, Pocovi A (2001) Thermal history during Mesozoic extension and Tertiary uplift in the Cameros Basin, northem Spain. Basin Res 13:91-111 
Morad S, Ketzer JM, De Ros F (2000) Spatial and temporal distribution of diagenetic alterations in siliciclastic rocks: Implications for mass ransfer in sedimentary basins. Sedimentology 47:95-120

-choa M, Arribas J, Mas R, Goldstein RH (2007) Destruction of a fluvial reservoir by hydrothermal activity. Sediment Geol 202:158-173

Plata A (1994) Composición isotópica de las precipitaciones y aguas subterráneas de la Península Ibérica: Centro de Estudios y Experimentación de Obras Públicas. Ministerio de Obras Públicas y Transportes, Madrid $140 \mathrm{p}$

Radke BM, Matthis RL (1980) On the formation and ocurrence of saddle dolomite. J Sediment Petrol 50:1149-1168

Rossi C, Goldstein RH, Ceriani A, Marfil R (2002) Fluid inclusions record thermal and fluid evolution in reservoir sandstones, Khatatba Formation, Western Desert, Egypt: a case for fluid injection. AAPG Bull 86:1773-1799

Rush GB, Reed MH (2005) Scanning electron microscope-cathodoluminiscence analysis of quartz reveals complex growth histories in veins for the Butte porphyry copper deposit, Montana. Geol 30(8):727-730

Rush GB, Reed MH, Dilles JH, Kent AJR, Dypvik H, Goles GG (2006) Intensity of quartz cathodoluminiscence and traceelement content in quartz from the porphyry copper deposit at Butte, Montana. Am Mineral 91:1300-1312
Salas R, Guimerá J, Mas R, Marín-Closas C, Meléndez A, Alonso A (2001) Evolution of the mesozoic central iberian rift system and its cainozoic inversion (Iberian Chain). In: Cavazza W, Roberson AHFR, Ziegler P (eds) Peri-Tethyan Rift- Wrench Basins and Passive Margins. Mém Mus Nat d' Hist Natur 186:145-185

Spötl C, Pitman JK (1998) Saddle (baroque) dolomite in carbonates and sandstones: a reppraisal of a burial-diagenetic concept. In: Mora S (ed) Carbonate cementation in sandstones. IAS Special Publ 26:437-460

Taylor HJR (1974) The applications of oxygen and hydrogen isotope studies to problems of hydrothermal alteration and ore deposiion. Econ Geol 69:843-883

Turgarinov AI, Vernadsky VI (1970) Dependance of the decrepitation temperature of minerals on their gas-liquid inclusions and hardness. Akademiya Nauk Doklady 195:112-114

Villalaín JJ, Fernández-González G, Casas AM, Gil-Imaz A (2003) Evidence of a Cretaceous remagnetization in the Cameros Basin (North Spain): implications for basin geometry. Tectonophys 377:101-117

Waples DW (1980) Time and temperature in petroleum formation: application of Lopatin's method to petroleum exploration. AAPG Bull 64:916-926 